\title{
Multidimensional Innovation, Heterogeneity of Property Rights and Enterprise Productivity
}

\author{
Shujun Wang ${ }^{1, a}$ \\ ${ }^{1}$ Chengdu College of University of Electronic Science and Technology of China, Chengdu, China
}

\begin{abstract}
This paper constructed a fixed effect model of panel data, taking the full factor productivity as a measure of enterprise productivity. This paper empirically studies the effect of multi-dimensional innovation on enterprise productivity, examining the relationship between multi-dimensional innovation level and enterprise productivity of different ownership enterprises. This paper finds that the multidimensional innovation of almost all types of enterprises take a notable promotion role on their productivity on the whole, while the specific dimensions have different effects. In the end, this paper analyzes the causes of this situation, which also proposes the corresponding suggestions.
\end{abstract}

\section{Introduction}

At present, China's economic development is in a new normal that the economic growth has developed from the past high-speed growth to high-quality growth. The report of the Nineteenth National Congress of the Communist Party of China pointed out that innovation is the first motive power to lead development as well as the strategic support for constructing a modern economic system. During the process of persisting in the "innovative development", there is a question that the government and enterprises need to consider what measures can be taken to promote innovation for the sake of further promote the improvement of social productivity, thus continuously promote China's economic growth rate. However, the existing researches are mostly from the macroeconomic point of view, which lay stress on the relationship between innovation and the overall growth of the economy from the national, industrial or regional level. However, starting from the micro-enterprise level, this paper discusses the promotion effect of multi-dimensional innovation on enterprise productivity to provide basis under the background of heterogeneity of property rights, which provides the support for promoting "innovative development" in China.

\section{Literature review and research assumption}

\subsection{Literature review}

The existing literature on the relationship between innovation and productivity mainly lay stress on the contribution of innovation to productivity and economic development. Foreign scholars measure innovation activities mainly by taking the advantages of the research and development investment and return, measuring the private and social returns of research and development investment and total factor productivity, and the influence of research and development investment on economic growth (Griliches, 1986; 1996; Harhoff, 1998; Dilling-Hansen, 2000, etc.). In addition, Griliches(1986), Lichtenberg and Donald(1991) estimated the research and development investmentreturns of U.S. manufacturing enterprises to be between $10 \%$ and $39 \%$ by using the research and development intensity model. Goto and Suzuki(1989) estimated the earning rate of the research and development in Japanese manufacturing enterprises is about 40\%. Zhang Ocean (2005) and Li Xuefeng (2005) point out that the impact of innovation on China's total factor growth rate is not significant. However, studies by He Wei (2003), Li Mingzhi and Wang Yali (2005), Wang Yingwei and Hecheng Bangwen (2005), Li Hongzhi (2006), Wang Ling (2008) and others showed that innovation is a significant factor in promoting China's economic growth.

It can be seen that there are great differences among different research results. The reason may be that the variables selected in the literature, the measurement

afishwaterjane@126.com 
models designed, the measurement methods adopted, the data types selected are different, the time limit of the data samples, the countries, regions and industries from which the data come are different, and the research results are often quite different. Moreover, most researches only take the use of the research and development expenditure as an index to measure the innovation of industries or enterprises, which do not take into account of the influence of different dimensions of innovation on productivity. Meanwhile, there is few researches on the relationship between innovation and productivity of micro-enterprises in China. However, most of researches only take into account industrial enterprises or high-tech enterprises, which do not think over the influence of heterogeneity of property rights on enterprise productivity.

\subsection{Research assumptions}

Innovation is not a single activity, but multi-dimensional and multi-level. From the four dimensions of innovation intensity, innovation scope, innovation achievement and learning effect, this paper comprehensively measures the innovation activities of enterprises and proposes the following four assumptions.

Assumption 1: Innovation intensity is positively related to enterprise productivity. The innovation intensity reflects the research and development density of the enterprise. The higher the innovation intensity indicates the more active the innovation activities of the enterprise, which has the greater the promotion effect on the productivity of the enterprise.

Assumption 2: The scope of innovation is positively related to enterprise productivity. The scope of innovation is reflected in the degree of outsourcing of enterprises. The higher the degree of outsourcing indicates the more concentrated the enterprise on its core competitiveness, which has the higher the degree of innovation within its core competitiveness and the higher the productivity of the enterprise. In general, the enterprise's innovation scope with the higher the degree of outsourcing is more likely in the research and development field, marketing field or organizational structure and operation field. Moreover, if the enterprise heavily depends on purchasing external spare parts to product, indicating that the enterprise may adopt the standardized or modular mode of production, which means the enterprise may be more productive."

Assumption 3: The scope of innovation is positively related to enterprise productivity. To a certain extent, the innovation results not only reflect the market coverage of new products, but also reflects the degree of commercialization of enterprise innovation. If the higher the proportion of new product output value in sales, indicating that the innovation of the enterprise is more effective, thus the enterprise may be more productive.

Assumption 4: Learning effect is positively related to enterprise productivity. If the greater the investment in employee training, there will be more possibilities that the quality and ability of employees will be improved. Learning effect has brought the average cost of enterprises to decline day by day, thus improving the productivity of enterprises.

\section{Design of research}

\subsection{Data description}

The sample data of this paper is micro-panel data, derived from the statistical report database of industrial enterprises in recent years, covering all state-owned enterprises and larger non-state-owned enterprises with main business income of more than 5 million yuan.

\subsection{Main variables}

1. Enterprise productivity. Based on the existing literature, this paper adopts total factor productivity as an indicator to measure enterprise productivity, using the method of transcendental logarithmic production function to estimate the total factor productivity of each sample enterprise.

2. Multi-dimensional innovation. Among them, innovation intensity $=$ research and development input/sales of enterprises; Scope of innovation = intermediate investment/gross output value of enterprises; Innovation results $=$ output value/sales value of new products of enterprises; Learning effect $=$ per capita training investment of enterprises.

3. Control variables. Enterprise size: the sales value to measure enterprise size. Capital intensity: the per capita capital of enterprises to measure the capital intensity level of enterprises. Export: this paper sets up whether the enterprise has a virtual variable of export delivery value. If yes, the value is 1 ; If not, the value is 0 .

\subsection{Model construction}

The basic form of the model is:

$T F P_{i j k}=\alpha_{0}+\alpha_{1} \cdot \operatorname{lag}_{-} r d_{-}$sale $_{i j k}+\alpha_{2} \cdot \operatorname{lag} \_$outsource $e_{i j k}+$ $\alpha_{3} \cdot$ newpro_sale $_{i j k}+\alpha_{4} \cdot r_{-}$train $_{i j k}+\alpha_{5} \cdot e_{i j k}+\alpha_{6} \cdot \ln _{-}$sale $_{i j k}+\alpha_{47} \cdot r_{-}$capital $_{j k}+\varepsilon_{i j k}$ In light of the possible lag effect of innovation investment measured by enterprise research and development investment, intermediate investment and training investment, this paper uses the enterprise innovation intensity of the lag phase, innovation scope and learning effect indicators to explain the effect of innovation on productivity.

Specific variable definitions and symbol settings are shown in Table I.

TABLE I. DEFINITIONS AND SYMBOLS OF VARIABLES

\begin{tabular}{|l|l|l|l|}
\hline \multicolumn{2}{|c|}{ Variable } & Symbol & \multicolumn{1}{c|}{ Definition } \\
\hline $\begin{array}{l}\text { Depe } \\
\text { nden } \\
\boldsymbol{t} \\
\text { varia } \\
\text { ble }\end{array}$ & $\begin{array}{l}\text { Enterprise } \\
\text { productivi } \\
\text { ty }\end{array}$ & TFP & $\begin{array}{l}\text { Total factor } \\
\text { productivity }\end{array}$ \\
\hline $\begin{array}{l}\text { Expl } \\
\text { anat }\end{array}$ & $\begin{array}{l}\text { Innovation } \\
\text { intensity }\end{array}$ & $\begin{array}{l}\text { lag_rd_ } \\
\text { sale }\end{array}$ & R\&D input/sales \\
\hline
\end{tabular}




\begin{tabular}{|c|c|c|c|}
\hline \multirow{3}{*}{$\begin{array}{l}\text { ory } \\
\text { varia } \\
\text { ble }\end{array}$} & $\begin{array}{l}\text { Innovation } \\
\text { scope }\end{array}$ & $\begin{array}{l}\text { lag_out } \\
\text { source }\end{array}$ & $\begin{array}{l}\text { Intermediate } \\
\text { input/output value }\end{array}$ \\
\hline & $\begin{array}{l}\text { Innovation } \\
\text { outcome }\end{array}$ & $\begin{array}{l}\text { newpro } \\
\text { _sale }\end{array}$ & \begin{tabular}{llr} 
Output & \multicolumn{2}{l}{ value/sales } \\
value & of & new \\
products & &
\end{tabular} \\
\hline & $\begin{array}{l}\text { Learning } \\
\text { effect }\end{array}$ & $\begin{array}{l}\text { lag_r_tr } \\
\text { ain }\end{array}$ & $\begin{array}{l}\text { Per capita training } \\
\text { input }\end{array}$ \\
\hline \multirow{3}{*}{$\begin{array}{l}\text { Cont } \\
\text { rol } \\
\text { varia } \\
\text { ble }\end{array}$} & $\begin{array}{l}\text { Enterprise } \\
\text { scale }\end{array}$ & ln_sale & Sales volume \\
\hline & $\begin{array}{l}\text { Capital } \\
\text { intensity }\end{array}$ & $\begin{array}{l}\text { r_capita } \\
1\end{array}$ & Per capita capital \\
\hline & Export & ex & 1 is Yes, 0 is None \\
\hline
\end{tabular}

\section{Empirical results and analysis}

\subsection{Descriptive statistics}

Table II shows the statistical characteristics of the main variables under the heterogeneity of property rights. It can be seen that there are obvious differences between multi-dimensional innovation and enterprise productivity level under the heterogeneous of property rights.

TABLE II. Statistical Characteristics of MAin VARIABles Under Heterogeneity of Property Rights

\begin{tabular}{|l|l|l|l|l|l|l|}
\hline \multirow{2}{*}{} & \multicolumn{2}{|l|}{ Average value } & \multicolumn{2}{|l|}{ Standard deviation } \\
\cline { 2 - 6 } & $\begin{array}{l}\text { Exclusiv } \\
\text { ely } \\
\text { foreign- } \\
\text { owned } \\
\text { enterpris } \\
\text { es }\end{array}$ & $\begin{array}{l}\text { Private } \\
\text { enterprise }\end{array}$ & $\begin{array}{l}\text { State- } \\
\text { owned } \\
\text { enterprise }\end{array}$ & $\begin{array}{l}\text { Exclusive } \\
\text { ly } \\
\text { foreign- } \\
\text { owned } \\
\text { enterprise } \\
\text { s }\end{array}$ & $\begin{array}{l}\text { Private } \\
\text { enterprise }\end{array}$ & $\begin{array}{l}\text { State- } \\
\text { owned } \\
\text { enterprise }\end{array}$ \\
\hline $\begin{array}{l}\text { Enterprise } \\
\text { productivity }\end{array}$ & 6.8389 & 6.4759 & 6.0189 & 1.0902 & 0.9517 & 1.3390 \\
\hline $\begin{array}{l}\text { Innovation } \\
\text { intensity }\end{array}$ & 0.0014 & 0.0016 & 0.0013 & 0.0094 & 0.0239 & 0.0148 \\
\hline $\begin{array}{l}\text { Innovation } \\
\text { scope }\end{array}$ & 0.7522 & 0.7863 & 0.7840 & 0.7430 & 0.5290 & 2.7727 \\
\hline $\begin{array}{l}\text { Innovation } \\
\text { outcome }\end{array}$ & 0.0406 & 0.0326 & 0.0260 & 0.1971 & 0.2544 & 0.1489 \\
\hline $\begin{array}{l}\text { Learning } \\
\text { effect }\end{array}$ & 0.0148 & 0.0814 & 0.0695 & 0.8562 & 0.3919 & 0.3293 \\
\hline
\end{tabular}

\subsection{Regression results}

Firstly, this paper excludes the multicollinearity between explanatory variables through correlation coefficient analysis and variance expansion factor analysis. Then, this paper determines to adopt the fixed effect model for regression through the individual effect significance test, the Brucci-Bacon test and the houseman test, and the results are shown in Table III.

TABLE III. FIXED EFFECT MODEL OF INNOVATION IMPACT ON ENTERPRise Productivity

\begin{tabular}{|l|l|l|l|l|}
\hline & Total sample & $\begin{array}{l}\text { Exclusively } \\
\text { foreign-owned } \\
\text { enterprises }\end{array}$ & $\begin{array}{l}\text { Private } \\
\text { enterprise }\end{array}$ & $\begin{array}{l}\text { State-owned } \\
\text { enterprise }\end{array}$ \\
\hline $\begin{array}{l}\text { Innovation } \\
\text { intensity }\end{array}$ & $\begin{array}{l}0.0195 \\
(0.27)\end{array}$ & $\begin{array}{l}-1.4836 \\
(-1.76)^{*}\end{array}$ & $\begin{array}{l}0.2003 \\
(0.68)\end{array}$ & $\begin{array}{l}0.0944 \\
(0.50)\end{array}$ \\
\hline $\begin{array}{l}\text { Innovation } \\
\text { scope }\end{array}$ & $\begin{array}{l}0.0067 \\
(2.80)^{* * *}\end{array}$ & $\begin{array}{l}0.2908 \\
(10.72)^{* * *}\end{array}$ & $\begin{array}{l}0.0531 \\
(9.51)^{* * *}\end{array}$ & -0.0117 \\
$(-4.22)^{* * *}$
\end{tabular}




\begin{tabular}{|c|c|c|c|c|}
\hline Export & $\begin{array}{l}-0.0311 \\
(-3.76)^{* * *}\end{array}$ & $\begin{array}{l}-0.0765 \\
(-2.96)^{* * *}\end{array}$ & $\begin{array}{l}-0.0318 \\
(-2.95)^{* * *}\end{array}$ & $\begin{array}{l}-0.0016 \\
(0.07)\end{array}$ \\
\hline $\begin{array}{l}\text { Enterprise } \\
\text { scale }\end{array}$ & $\begin{array}{l}0.7681 \\
(211.98)^{* * * *}\end{array}$ & $\begin{array}{l}0.7376 \\
(46.56)^{* * *}\end{array}$ & $\begin{array}{l}0.7336 \\
(142.13)^{* * *}\end{array}$ & $\begin{array}{l}0.8173 \\
(128.19)^{* * *}\end{array}$ \\
\hline $\begin{array}{l}\text { Capital } \\
\text { intensity }\end{array}$ & $\begin{array}{l}0.0002 \\
(15.11)^{* * *}\end{array}$ & $\begin{array}{l}0.0001 \\
(3.26)^{* * *}\end{array}$ & $\begin{array}{l}0.0003 \\
(10.65)^{* * *}\end{array}$ & $\begin{array}{l}0.0004 \\
(11.52)^{* * *}\end{array}$ \\
\hline Constant term & $\begin{array}{l}-1.0946 \\
(-30.36) * * *\end{array}$ & $\begin{array}{l}-1.0234 \\
(-6.09)^{* * *}\end{array}$ & $\begin{array}{l}-0.7382 \\
(-14.37)^{* * *}\end{array}$ & $\begin{array}{l}-1.6085 \\
(-26.43)^{* * *}\end{array}$ \\
\hline$R$-squared & 0.4639 & 0.4366 & 0.3986 & 0.4987 \\
\hline F-test & $6475.46^{* * *}$ & $339.90 * * *$ & $2939.49 * * *$ & $2361.52 * * *$ \\
\hline $\begin{array}{l}\text { Sample } \\
\text { number }\end{array}$ & 247367 & 23228 & 126461 & 66836 \\
\hline
\end{tabular}

It can be found that multi-dimensional innovation can significantly promote the productivity of enterprises. However, different dimensions of innovation have different forces. The innovation intensity has not significant effect on enterprise productivity. It is showed that the main factors that promote the growth of Chinese enterprises are not the increase of research and development investment, but the consumption of resources, labor input and capital investment. The scope of innovation has a significant contribution to enterprise productivity. The reason may be that enterprises with high degree of outsourcing adopt more standardized or modular production methods, coupled with organizational innovation of enterprises, which results in greater productivity. Innovation outcomes also contribute significantly to the productivity of enterprises. It is showed that the higher the proportion of new product output value in sales, the higher the degree of marketization or commercialization of enterprise innovation, and the more effective the enterprise innovation, all of which result in the increase of enterprise productivity. The learning effect has no significant effect on the productivity of enterprises. It may be because the training of employees is a long-term gradual accumulation process, while the average cost reduction of enterprises is also a slow process. Therefore, the per capita training input, which has lagged only one period, does not have a significant effect on enterprise productivity.

\section{Conclusions and recommendations}

This paper makes an empirical study on the impact of multi-dimensional innovation on the productivity of enterprises, and specifically analyzes the situation and causes of enterprises with different ownership under the condition of heterogeneity of property rights. In this paper, it is found that although the multi-dimensional innovation of different types of enterprises has obviously promoted the improvement of their own productivity on the whole, the effect of innovation intensity and learning effect is not obvious, indicating that the innovation quality of Chinese enterprises still needs to be improved. Therefore, in the process of insisting on the "innovation development" era, China must start from the microeconomic level of enterprises, increasing investment of the innovation, improving the management mechanism and governance structure of enterprises, setting up an innovative enterprise culture, enhancing the cultivation of high-quality talents, effectively intensifying the independent innovation ability and core competitiveness of enterprises, making the innovation promotion effect of enterprises spread to different industries and different regions, which can establish a sustainable, efficient and continuous development path for China's economic growth.

\section{References}

1. Kubota Keiichi, Takehara Hitoshi. Firm-level innovation by Japanese family firms: Empirical analysis using multidimensional innovation measures. Pacific-Basin Finance Journal 10.1016/j.pacfin.2018.05.012.

2. Englander, A., Evenson, R. and Hanazaki, Mi , "R\&D, Innovation, and the Total Factor Productivity Slowdown", OECD Economic Studies, 11,1988, p.7-42.

3. Jefferson, G.H. , Bai Huamao, Guan Xiaojing and $\mathrm{Yu}$ Xiaoyun, "R\&D Performance in Chinese Industry", Economics of Innovation and New Technology, 13(1/2), 2004. 